\title{
Pre-packing cooling and types of packages in maintaining physiological quality of soybean seeds during storage ${ }^{1}$
}

\author{
Everson Reis Carvalho ${ }^{2 *}$, João Almir Oliveira ${ }^{3}$, Denilson Paulo da Rosa \\ Mavaieie $^{3}$, Hellismar Wakson da Silva ${ }^{3}$, Cassiano Gabriel Moreira Lopes ${ }^{3}$
}

\begin{abstract}
Seeds storing under appropriate conditions reduces the speed of the seeds deterioration process. The aim of this study was to evaluate pre-packing cooling and types of packages in the maintenance of the physiological quality of soybean seeds during storage. The completely randomized experimental design was used, with four replications, considering a factorial arrangement involving or not the pre-packing cooling of the seed mass, three types of packages (multi-layer paper bag, big bag, and polyethylene container), and five storing periods ( $0,2,4,6$ and 8 months). The physiological quality was evaluated by the tests of first germination count, germination, accelerated aging, electrical conductivity, emergence speed index and emergence. The use of packages with larger amount of seeds (big bag and polyethylene container) did not favor the maintenance of the pre-packing cooling temperature. The types of packages did not show significant differences in the seeds viability during storage, up to eight months, regardless the pre-packing cooling. The cultivars seeds showed different tolerance to storing, i.e. seeds of the cultivar TMG 1176 had lower storing potential comparing to the seeds from the cultivar SYN 9074.
\end{abstract}

Index terms: germination, Glycine max, storability, storing conditions, vigor.

\section{Resfriamento pré-envase e tipo de embalagem na manutenção da qualidade fisiológica de sementes de soja ao longo do armazenamento}

\begin{abstract}
RESUMO - O armazenamento de sementes sob condições adequadas reduz a velocidade do processo de deterioração de semente. O objetivo com o trabalho foi avaliar o resfriamento pré-envase e tipos de embalagem na manutenção da qualidade de sementes de soja ao longo do armazenamento. Utilizou-se o delineamento experimental inteiramente casualizado com quatro repetições, em arranjo fatorial envolvendo ou não o resfriamento da massa de sementes antes do envase, três tipos de embalagens (sacaria de papel multifoliado, big bag e contêiner em polietileno) e cinco épocas de armazenamento (0, 2, 4, 6 e 8 meses). A qualidade fisiológica foi avaliada por meio de testes de primeira contagem de germinação, germinação, envelhecimento acelerado, condutividade elétrica, índice de velocidade de emergência e emergência. O uso de embalagens com maiores quantidades de sementes (big bag e contêiner) não favoreceu a manutenção da temperatura do resfriamento pré-envase. Os tipos de embalagem não proporcionaram diferenças na viabilidade de sementes de soja ao longo do armazenamento, até oito meses, independente do resfriamento antes do envase. As sementes das cultivares apresentaram diferentes tolerâncias ao armazenamento, sendo que as sementes da cultivar TMG 1176 RR possuem menor potencial de armazenamento em relação às sementes da cultivar SYN 9074 RR.
\end{abstract}

Termos para indexação: armazenabilidade, condições de armazenamento, germinação, Glycine max, vigor.

\section{Introduction}

Soybean crops (Glycine max (L.) Merrill) is among the most important crops in the national agricultural scene, whether by its currency generation through exportation or by its industrial use with the development of many different soy derived products (Ávila and Albrecht, 2010).

With the advance of agricultural borders in soybean

${ }^{1}$ Submitted on 02/19/2016. Accepted for publication on 05/13/2016.

${ }^{2}$ Universidade Federal de Uberlândia, 38500-000 - Monte Carmelo, MG, Brasil. production, especially in regions with a hot and humid weather (Villela and Menezes, 2009), the seed quality in the sowing period holds great importance for the acquisition of satisfactory production. This justifies the increasing demand and need of the use of high quality seeds (Vieira et al., 2010; Carvalho et al., 2014a). Villela and Menezes (2009) highlighted the need of adopting modern post-harvest techniques which allows the conservation and quality of the seeds, ensures the maintenance

${ }^{3}$ Departamento de Agricultura, Universidade Federal de Lavras, Caixa Postal 3037, 37200-000 - Lavras, MG, Brasil.

*Corresponding author <ercarvalho@ufu.br> 
of germination and minimizes vigor reduction.

Storage is a relevant step in soybean production, especially in some regions of Brazil, where there is weather conditions show high temperatures and relative humidity (Zuchi et al., 2013). According to Toledo et al. (2009), the capacity of quality maintenance of seeds during the storage period is influenced by many factors, such as the water content that the seeds were stored with, conservation packages, temperature and relative humidity of the air during the storage. The use of proper packages during storage is essential to the maintenance of the physiological quality. The packages, depending on its properties, might reduce or obstruct the water vapor exchanges between the seeds and the external environment, keeping the initial water content of the seeds (Cardoso et al., 2012; Bessa et al., 2015).

The temperature and relative humidity of the air, during the storage process, are of great importance in the deterioration evolution, which cannot be avoided but can be minimized in storage under appropriate conditions, such as control of temperature and relative humidity of the ambient (Santos et al., 2004). Conditions of low temperature and low relative humidity of the air enable the reduction of the seed respiratory activity and, consequently, the speed of the deterioration process (Carvalho and Nakagawa, 2012; Lima et al., 2014; Smaniotto et al., 2014).

Some of the soybean productive regions in Brazil are characterized by high temperatures throughout the entire year, which makes it difficult to maintain the quality of the seed over the storage in the intercrop period. Smiderle and Gianluppi (2006), with a study held in Roraima, Brazil, reported that the association of an air relative humidity of $70 \%$ with temperatures close to $25^{\circ} \mathrm{C}$ ensures a good storage condition in that region. Aguiar et al. (2012) verified that soybean seeds maintained a high germination when stored under a temperature of $25^{\circ} \mathrm{C}$, especially when associated with a modified atmosphere with $\mathrm{CO}_{2}$, in relation to $31^{\circ} \mathrm{C}$.

In order to minimize the effects of high temperature in storage, some techniques can be used, such as artificial cooling of the warehouse. However, it presents high deployment and maintenance costs. Thus, the use of the mass artificial cooling of the seeds technique before packaging and storage is an option, Demito and Afonso (2009) determined benefic effects of this technique in the maintenance of the soybean seeds quality stored in environmental conditions in Hernandárias, Paraguay, and secured in tangled $40 \mathrm{~kg}$ woven polypropylene bags. The success is based on the maintenance possibility of the initial stored seed temperature in safe levels, without the need of a new cooling cycle (Demito and Afonso, 2009). Zuchi et al. (2013), working with soybean seeds artificially cooled to $18{ }^{\circ} \mathrm{C}$ through a dynamic process and stored in multi-layer Kraft paper $(40 \mathrm{~kg})$ in an environment not controlled in Campo Verde, Mato Grosso, Brazil, reported a slight superiority of cooled soybean seeds in the maintenance of physiological quality, however for lots of high physiological performance those advantages were not observed. Therefore, the benefits of the use of pre-packaging cooling are not established yet.

Often, in the seed production process, the use of storing in high capacity packages, $1000 \mathrm{~kg}$, for example, is necessary for cost reductions and logistics optimization. Besides, the combination between seed mass cooling and high capacity storing constitutes a promising option, due to the dry seed characteristic related to thermic isolation. Studies that relate this combination and the soybean seed quality throughout storage are scarce. They are necessary to evaluate and adapt these technologies to the storing of high quality soybean seeds, especially in regions where temperatures during intercrop are elevated, as in the CentralWest region, biggest soybean producer in Brazil. Therefore, the objective of this research is to evaluate cooling and type of package in the maintenance of soybean seed quality during storage in Mato Grosso state, Brazil.

\section{Material and Methods}

The research was held in partnership with the AMAGGI Group, seed division, Campo Novo do Parecis, Mato Grosso, and the Universidade Federal de Lavras (UFLA), in Lavras, Minas Gerais, Brazil. Soybean seeds from the cultivars TMG 1176 RR and SYN 9074 RR were used and the seed lots were produced by the company AMAGGI, in similar conditions. The seeds were dried in a stationary dryer with forced circulation of the air in $38{ }^{\circ} \mathrm{C}$, until they achieve $12 \%$ of water content; the lots were processed in the same way. There were utilized seeds with similar initial characteristics for germination and vigor.

About the seed mass cooling, part of the seeds was artificially cooled until it reached $13{ }^{\circ} \mathrm{C}$, using the proper air cooling equipment, before storing in the packages and the other part was not cooled before storing. The seeds were stored in three types of packages: multi-layer Kraft paper (paper bag, $40 \mathrm{~kg}$ capacity), woven polypropylene (big bags, $1000 \mathrm{~kg}$ capacity) and high density polyethylene molded containers (PEAD, with lid, $1000 \mathrm{~kg}$ capacity). After packaging, the seeds were stored in the conventional storage unit (uncontrolled temperature and relative humidity) in Campo Novo do Parecis, Mato Grosso, Brazil. The temperature monitoring was done weekly 50 centimeters deep in the seed mass.

During the storage period, evaluations on the seed physiological quality were held in $0,2,4,6$ and 8 months. 
The physiological quality of the seeds was evaluated in the Central Seed Analysis Laboratory, UFLA, Lavras, MG, through these tests:

Germination: four 50 seeds replications were used, sowed in towel paper ( 3 sheets) moistened with distilled water in an amount 2.5 times the dry paper weight. The rolls were kept in a germinator at $25{ }^{\circ} \mathrm{C}$. The evaluation was held eight days after the sowing and the results were expressed by normal seedlings percentage (Brasil, 2009).

First germination count: together with the germination test, seedling evaluations were held five days after sowing, and the results were expressed by normal seedlings percentage (BRASIL, 2009).

Emergence under controlled conditions: sowing was conducted in plastic trays with substrate made of soil + sand in the proportion of 2:1, with four replicates of 50 seeds. After the sowing, the trays were kept in a vegetal growth chamber at a temperature of $25^{\circ} \mathrm{C}$, alternate light-dark regime (12 hours). Right after the emergence of the first seedling, cotyledons completely out of the substrate, daily monitoring was held to evaluate the number of emerged seedlings, until stabilization. It was considered the percentage of normal seedlings in the 14th day $(\% \mathrm{E})$ and the emergence speed index (EVI), determined according to Maguire (1962).

Accelerated aging: it was conducted in gerbox-type transparent acrylic boxes, adapted with a hanging aluminum screen, where the seeds were placed in a single layer; $40 \mathrm{~mL}$ of distilled water were added on the bottom of the boxes. The boxes were kept at $42{ }^{\circ} \mathrm{C}$ for 48 hours in a BOD type chamber (Marcos - Filho, 1999). Subsequently, the seeds were submitted to the germination test, evaluating the normal seedling percentage in the 5th day according to Brasil (2009).

Electrical conductivity: the seeds were weighted and packaged in plastic cups with $75 \mathrm{~mL}$ of deionized water and kept at $25{ }^{\circ} \mathrm{C}$ in a BOD type chamber, with four replicates of 50 seeds. After 24 hours of soaking, a reading of the electrical conductivity was done with a Digimed CD-21 conductivimeter, according to Vieira and Krzyzanowski (1999). The results were expressed in $\mu \mathrm{S} . \mathrm{cm}^{-1} \cdot \mathrm{g}^{-1}$.

The experimental design was completely randomized (CRD), with four replicates, in a factorial scheme 2 (with or without cooling of the seed mass before packaging) 33 (types of packages) x 5 (evaluation periods during storage). The analysis was held independently to each of the cultivars. The data were submitted to variance analysis using the software Sisvar ${ }^{\circledR}$ (Ferreira, 2011), by the $\mathrm{F}$ test, $\mathrm{p}<0.05$. When relevant, means were compared using the Tukey test at $5 \%$, or polynomial regressions were performed, with the selection of mathematical models significant at 5\%, with the highest coefficient of determination.

\section{Results and Discussion}

\section{Seed mass temperature}

After the seed mass cooling to $13{ }^{\circ} \mathrm{C}$ in pre-packaging, with a week of storage in uncontrolled conditions in Campo Novo do Parecis, Mato Grosso, Brazil, the seed mass temperatures of the cultivar TMG $1176 \mathrm{RR}$, regardless of the type of package, were back to the levels over $20{ }^{\circ} \mathrm{C}$ (Figure 1). For the SYN 9074 RR cultivar, the same behavior was observed, however with smaller rates until the second week of storage for the seeds that were cooled before packaging and packaged in big bags and containers.
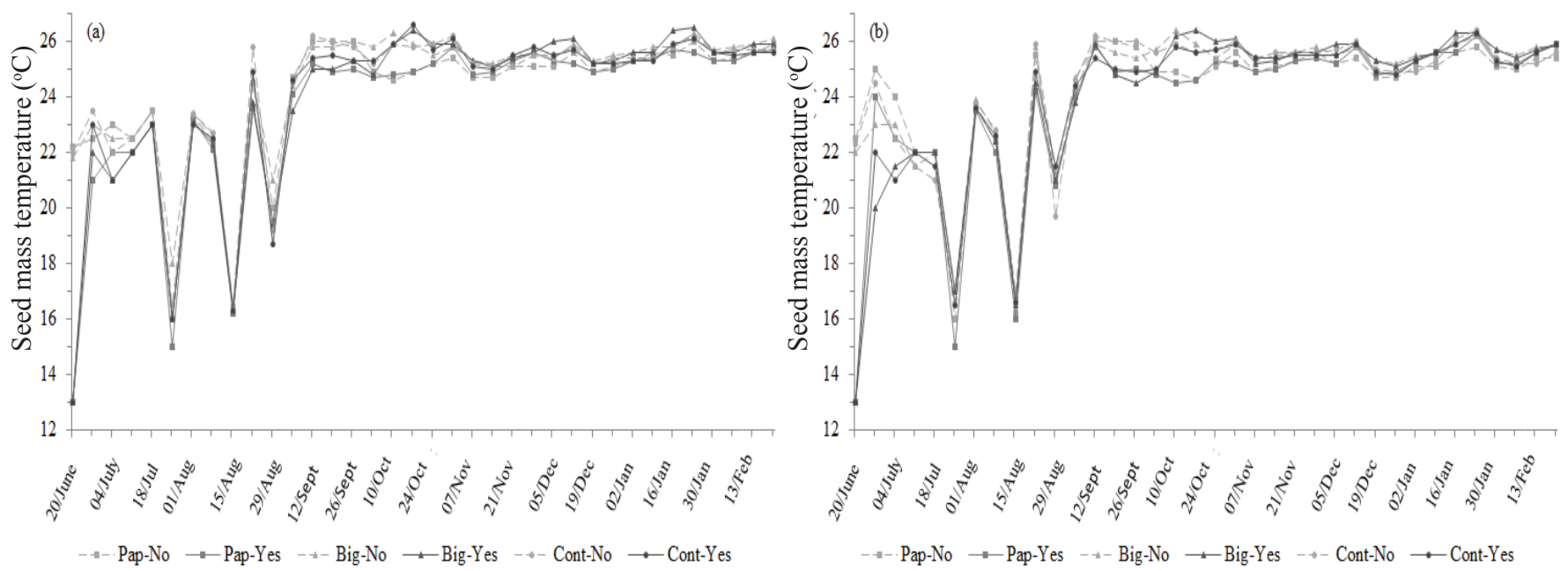

Figure 1. Temperature $\left({ }^{\circ} \mathrm{C}\right.$ ) of the seed mass, $50 \mathrm{~cm}$, from cultivars TMG 1176RR (a) and SYN 9074RR (b) not cooled (No) or cooled (Yes) before packaging and storage in different packages (Paper bag: Pap, Big Bag: Big, Container: Cont), during storage. 
The seed mass temperatures, with or without prepackaging cooling, maintained close rates after two weeks of storage, regardless the type and volume of the package (Figure 1). There was greater oscillation in June, July and August, the first months of storage, and after this period the mass temperatures were higher and practically constant during the other months (Figure 1). The variations happened due to the room temperature, which was not controlled and oscillated according to the climatic conditions of each season of the year in the region. Zuchi et al. (2013) reported lower temperatures in cooled seeds only in the first 15 days of storage in uncontrolled conditions in Mato Grosso, Brazil.

\section{Germination}

For the germination tests, with seeds from both cultivars cooled or not and stored in different types of package, there was significant effect as for the storage period (Figure 2). For the cultivar TMG 1176 RR (Figure 2a), it was verified a second degree tendency, with the determination coefficient $\mathrm{R}^{2} 86.5 \%$ and for the cultivar SYN 9074 RR (Figure 2b), a third degree tendency with determination coefficient of $\mathrm{R}^{2} 98.9 \%$. For the cultivar TMG $1176 \mathrm{RR}$, the germination was kept until two months of storage and, starting on this period there was reduction on germination, followed by accentuation after four months and especially after six months. However, for the cultivar SYN 9074 RR, the rates were stable until the fourth month and there was a prominent decrease after six months. Carvalho et al. (2014a) reported similar results, where starting from the sixth month of storage in uncontrolled conditions there was a drastic reduction on soybean seed germination. However, Almeida et al. (2010) found a linear loss of soybean seed germination stored for 180 days at ambient condition. In tropical conditions, Estevão (2002) reports loss in seed viability after 120 days of storage and Zuchi et al. (2013), regardless of the prepackaging cooling, a decrease after 60 days.
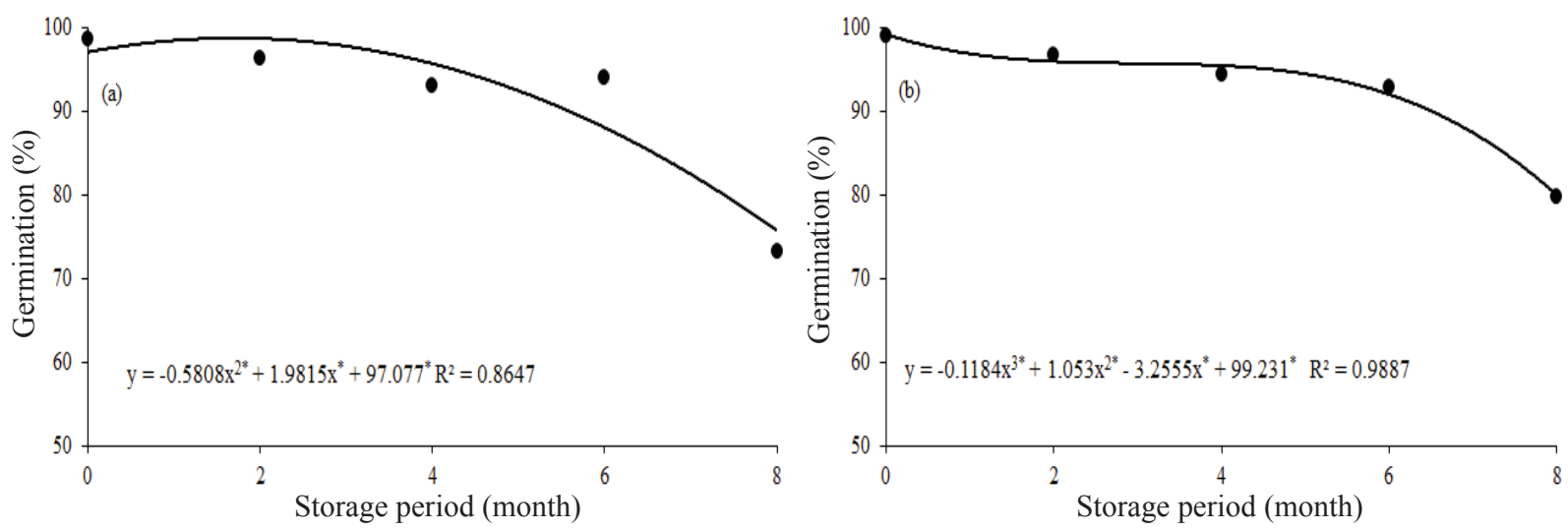

Figure 2. Seed germination from soybean cultivars TMG 1176RR (a) and SYN 9074RR (b) after different storage periods $(0$, 2, 4, 6 and 8 months).

\section{Accelerated aging}

For the estimated vigor through accelerated aging there was stability in the rates until four months of storage (Table 1). In six months and especially in eight months of storage, a decrease on seed vigor was observed for both cultivars. The seeds stored in paper bags showed higher averages when compared to other packages. Only in these two storage periods the seeds submitted to pre-packaging cooling presented superiorities, and big bags after six months for both cultivars and container for the cultivar TMG $1176 \mathrm{RR}$, and after eight months for the same cultivar in paper bags.

During storage it was verified that the second degree model was the best for seeds from the TMG 1176 RR cultivar without cooling (Figure 3a), and for the cultivar SYN 9074 RR when cooled (Figure 3d). In contrast, for the cooled cultivar TMG 1176 RR (Figure 3b) and not cooled SYN 9074 RR (Figure 3c), the effects were quadratic only for seeds stored in big bags, for the other seeds, the tendency was in the third degree.

The seed performance in each cultivar during storage was similar between the pre-packaging cooled seeds or the ones which weren't cooled and with similar tendencies regardless of the package type (Figure 3), differing only in the final storage periods (Table 1). Zuchi et al. (2013) haven’t noticed differences relating pre-packaging cooling.

Seeds from the TMG 1176 RR cultivar present a vigor reduction tendency before four months of storage, as reported in the regressions for pre-packaging cooled or not cooled seeds (Figure $3 a$ and $3 b$ ). Seeds from the SYN 
9074 RR cultivar, pre-packaging cooled or not cooled show, in general, prominent decrease on vigor after a four month storage, according to tendency lines (Figure 3c and 3d), a latter vigor reduction, which shows differences regarding the storage tolerance. Carvalho et al. (2014a) report that soybean genotypes show different levels of storing tolerance.

Table 1. Germination (\%) after the accelerated aging of the soybean seeds from cultivars TMG 1176RR and SYN 9074RR not cooled (NC) or cooled (C) before packaging and stored in different packages (Paper bag, Big Bag and Container), after storage periods $(0,2,4,6$ and 8 months).

\begin{tabular}{|c|c|c|c|c|c|c|c|c|c|c|}
\hline \multicolumn{11}{|c|}{ TMG 1176RR } \\
\hline \multirow{2}{*}{ Package } & \multicolumn{2}{|c|}{0} & \multicolumn{2}{|c|}{2} & \multicolumn{2}{|c|}{4} & \multicolumn{2}{|c|}{6} & \multicolumn{2}{|c|}{8} \\
\hline & $\mathrm{NC}$ & $\mathrm{C}$ & $\mathrm{NC}$ & $\mathrm{C}$ & $\mathrm{NC}$ & $\mathrm{C}$ & $\mathrm{NC}$ & $\mathrm{C}$ & $\mathrm{NC}$ & $\mathrm{C}$ \\
\hline Paper bag & $88 \mathrm{~b}$ & $88 \mathrm{~b}$ & $97 \mathrm{a}$ & $98 \mathrm{a}$ & $97 \mathrm{a}$ & $98 \mathrm{a}$ & $64 a$ & $62 \mathrm{a}$ & $22 \mathrm{Ba}$ & $40 \mathrm{Aa}$ \\
\hline Big Bag & $95 \mathrm{ab}$ & $93 \mathrm{ab}$ & $97 \mathrm{a}$ & $97 \mathrm{a}$ & $99 \mathrm{a}$ & $98 \mathrm{a}$ & $58 \mathrm{Bb}$ & $64 \mathrm{Aa}$ & $16 \mathrm{a}$ & $17 \mathrm{~b}$ \\
\hline Container & $99 \mathrm{a}$ & $97 \mathrm{a}$ & $99 \mathrm{a}$ & $99 \mathrm{a}$ & $93 \mathrm{a}$ & $97 \mathrm{a}$ & $30 \mathrm{Bc}$ & $40 \mathrm{Ab}$ & $7 \mathrm{~b}$ & $9 \mathrm{c}$ \\
\hline \multicolumn{11}{|c|}{ SYN 9074RR } \\
\hline \multirow{2}{*}{ Package } & \multicolumn{2}{|c|}{0} & \multicolumn{2}{|c|}{2} & \multicolumn{2}{|c|}{4} & \multicolumn{2}{|c|}{6} & \multicolumn{2}{|c|}{8} \\
\hline & $\mathrm{NC}$ & $\mathrm{C}$ & $\mathrm{NC}$ & $\mathrm{C}$ & $\mathrm{NC}$ & $\mathrm{C}$ & $\mathrm{NC}$ & $\mathrm{C}$ & $\mathrm{NC}$ & $\mathrm{C}$ \\
\hline Paper bag & $95 \mathrm{a}$ & $94 \mathrm{a}$ & $92 \mathrm{a}$ & $92 \mathrm{a}$ & $92 \mathrm{a}$ & $92 \mathrm{a}$ & $70 \mathrm{a}$ & $65 \mathrm{a}$ & $21 \mathrm{a}$ & $20 \mathrm{a}$ \\
\hline Big Bag & $96 \mathrm{a}$ & $94 \mathrm{a}$ & $91 \mathrm{a}$ & $92 \mathrm{a}$ & $89 a$ & $91 \mathrm{a}$ & $36 \mathrm{Bc}$ & $52 \mathrm{Ab}$ & $6 \mathrm{~b}$ & $7 \mathrm{~b}$ \\
\hline Container & $92 \mathrm{a}$ & $91 \mathrm{a}$ & $85 \mathrm{~b}$ & $89 \mathrm{a}$ & $93 \mathrm{a}$ & $90 \mathrm{a}$ & $56 b$ & $57 \mathrm{~b}$ & $8 \mathrm{~b}$ & $7 \mathrm{~b}$ \\
\hline
\end{tabular}

*Averages followed from the same lower case letter in the column do not differ between each other according to the Tukey test at $5 \%$. Capital letters in the line, in each storage period, present significant differences according to the variance analysis, $\mathrm{p}<0.05$ by the $\mathrm{F}$ test.
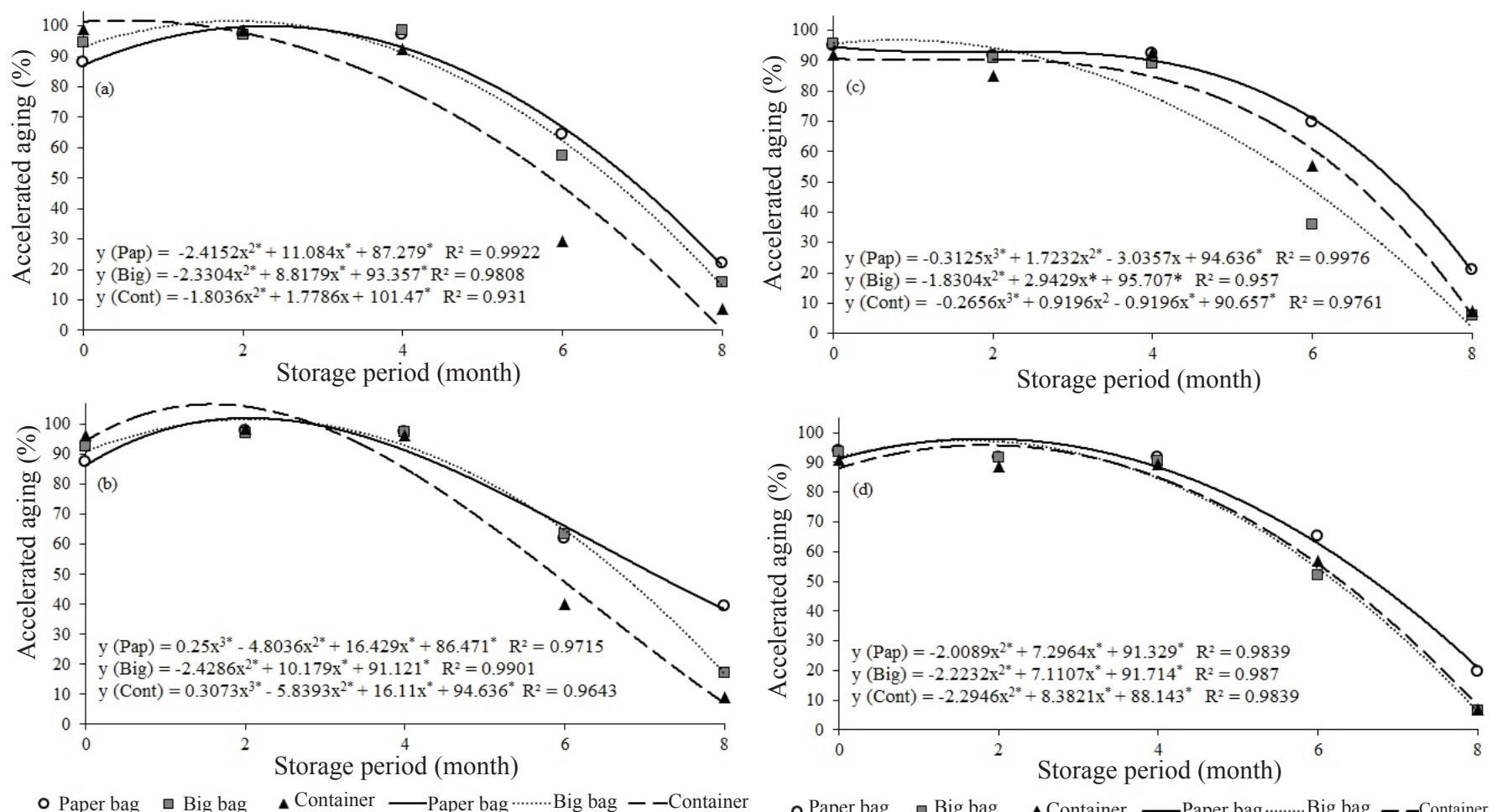

Figure 3. Germination (\%), after the accelerated ageing of soybean seeds from cultivars TMG 1176RR not cooled (a) and cooled (b) and SYN 9074RR not cooled (c) and cooled (d) before the packaging in different packages (Paper bags: Pap, Big Bag: Big, Container: Cont), after storage periods (0, 2, 4, 6 and 8 months).

In both cultivars, the vigor decrease was accentuated after six and especially in eight months, culminating with low vigor index at the end of storage (Table 1 and Figure 3).

For Carvalho et al. (2014a), in uncontrolled conditions, either 
vigor or germination is reduced especially after six months of storing. Cunha et al. (2009) reported soybean seed vigor reduction after six months of storage in cold chamber $\left(12{ }^{\circ} \mathrm{C}\right.$ and $65 \% \mathrm{UR}$ ).

\section{Seedling emergence}

For the seedling emergence, a significant effect occurred regarding storage (Figure 4). For TMG 1176 RR seeds stored in paper bags or big bags, the effect was in third degree, showing a small reduction at the end of the storage period (Figure 4a), between six and eight months. In contrast, for the seeds stored in containers, the effect was quadratic with a more accentuated decrease from the fourth month of storage on. The emergence percentage was kept with high and close values until the eight month of storage for the TMG $1176 \mathrm{RR}$ seed when stored in paper bags and big bags, which did not occur with those stored in containers at the final period. For SYN 9074 RR seeds, the storage effect was on third degree in all packages, and the values were high until 6 months, with a decrease in the eight month for all package types (Figure 4b).

Regarding the packages (Table 2), for TMG 1176 RR seeds, the emergence percentages were different in the four months of storage, with the seeds stored in paper bags with higher values than those in the container, and with eight months of storage the seeds from containers presented lower values. For SYN 9074 RR seeds, the differences appeared in the second month, with seeds stored in containers being higher than the ones in paper bags, and in the sixth and eight month, where the seeds kept in big bags were lower (Table 2). This might be related to what was debated regarding seed mass temperatures, where even in packages with different compositions and greater quantity of seeds, those were not efficient in the maintenance of lower temperatures for long periods.
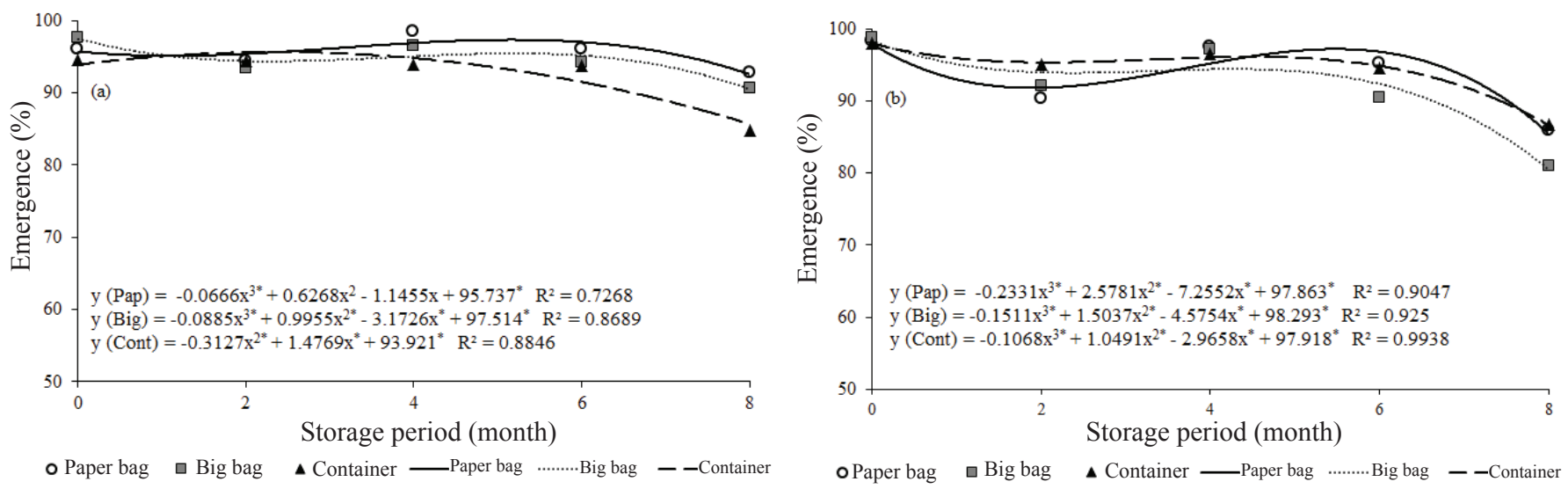

Figure 4. Emergence (\%) of soybean seeds from cultivars TMG 1176RR (a) and SYN 9074RR (b) stored in different packages (Paper bags: Pap, Big Bag: Big, Container: Cont), after different storage periods (0, 2, 4, 6 and 8 months).

Table 2. Emergence (\%) of the soybean seeds from cultivars TMG 1176RR and SYN 9074RR stored in different packages (Paper bags, Big Bag and Container), after different storage periods (0, 2, 4, 6 and 8 months).

\begin{tabular}{|c|c|c|c|c|c|c|c|c|c|c|}
\hline \multirow{3}{*}{ Package } & \multicolumn{5}{|c|}{ TMG 1176RR } & \multicolumn{5}{|c|}{ SYN 9074RR } \\
\hline & \multicolumn{5}{|c|}{ Storage Period (Month) } & \multicolumn{5}{|c|}{ Storage Period (Month) } \\
\hline & 0 & 2 & 4 & 6 & 8 & 0 & 2 & 4 & 6 & 8 \\
\hline Paper Bag & $96 \mathrm{a}$ & $95 \mathrm{a}$ & $99 \mathrm{a}$ & $96 \mathrm{a}$ & $93 \mathrm{a}$ & $98 \mathrm{a}$ & $91 \mathrm{~b}$ & $98 \mathrm{a}$ & $95 \mathrm{a}$ & $86 a$ \\
\hline Big Bag & 98 a & 94 a & $97 \mathrm{ab}$ & $94 \mathrm{a}$ & $91 \mathrm{a}$ & 99 a & $92 \mathrm{ab}$ & 97 a & $91 \mathrm{~b}$ & $81 \mathrm{~b}$ \\
\hline Container & $95 \mathrm{a}$ & $95 \mathrm{a}$ & $94 \mathrm{~b}$ & $94 \mathrm{a}$ & $85 \mathrm{~b}$ & $98 \mathrm{a}$ & $95 \mathrm{a}$ & 97 a & $95 \mathrm{a}$ & $87 \mathrm{a}$ \\
\hline
\end{tabular}

*Averages follow by the same lower case letters in the column do not differ between each other according to the Tukey test at $5 \%$.

In general, even after storing, the emergence percentages were high, with a slight decrease in the eight month. Juvino et al. (2014) observed that the soybean seed vigor was high during nine months of storage. Seed deterioration is inevitable, but it can be retarded, according to the storage conditions and the characteristics from the seed genotype.

\section{Emergence velocity index (EVI)}

For seeds from the cultivar TMG $1176 \mathrm{RR}$, the variation in the emergence velocity index (EVI) during storage were low (Figure 5a), and those differences might have been pointed out due to a low variation coefficient (6.85\%). Between the packages, the seeds 
stored in containers presented the lowest EVIs (Table 3). For SYN 9074 RR seeds, the trends were in the third degree during storage for all packages (Figure 5b), with a slight variation until month six, from where the decrease started. In seed kept in container, in the sixth month, there were observed the highest EVIs, which did not differ of those stored in paper bags (Table 3).
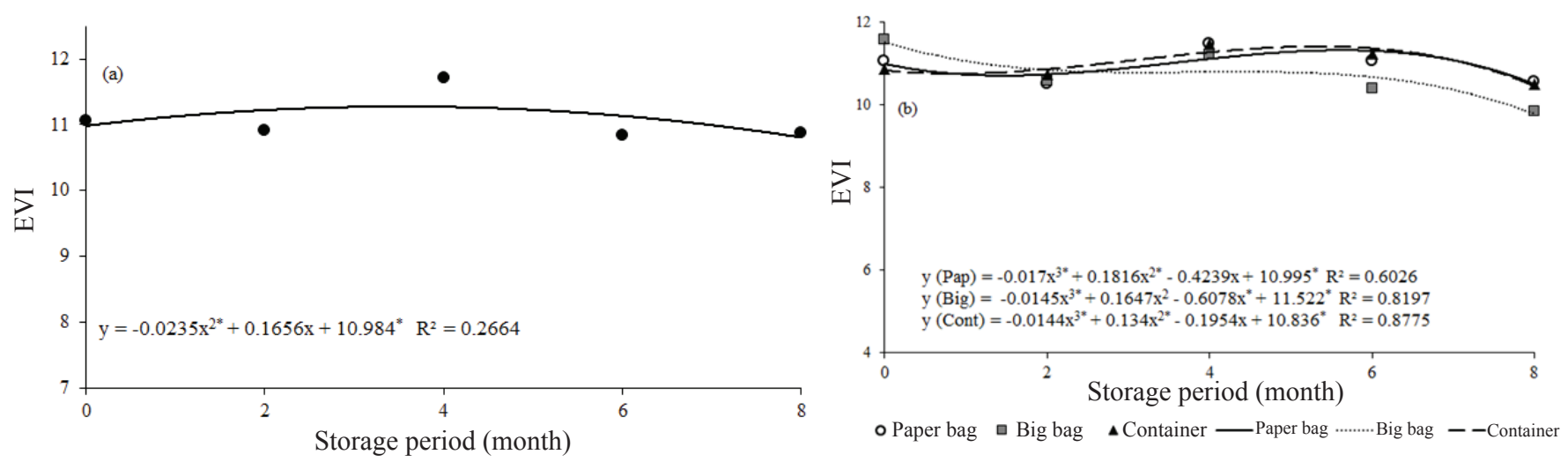

Figure 5. Emergence velocity index (EVI) of soybean seeds from cultivars TMG 1176RR (a) after storage periods $(0,2,4,6$ and 8 months) and SYN 9074RR (b) stored in different packages (Paper bags: Pap, Big Bag: Big, Container: Cont).

Table 3. Emergence velocity index (EVI) from seeds of the soybean cultivar TMG 1176RR depending on the package (Paper bags, Big Bag and Container) and of SYN 9074 stored in different packaging after storage periods.

\begin{tabular}{ccccccr}
\hline & & \multicolumn{5}{c}{ SYN 9074RR } \\
\cline { 3 - 6 } Package & TMG 1176RR & \multicolumn{5}{c}{ Storage Period (Month) } \\
\cline { 3 - 6 } & & 0 & 2 & 4 & 6 & $10.56 \mathrm{a}$ \\
& $11.33 \mathrm{a}$ & $11.05 \mathrm{a}$ & $10.49 \mathrm{a}$ & $11.48 \mathrm{a}$ & $11.06 \mathrm{ab}$ & $9.85 \mathrm{a}$ \\
Paper bag & $11.32 \mathrm{a}$ & $11.59 \mathrm{a}$ & $10.57 \mathrm{a}$ & $11.21 \mathrm{a}$ & $10.39 \mathrm{~b}$ & $10.49 \mathrm{a}$ \\
Big Bag & $10.59 \mathrm{~b}$ & $10.86 \mathrm{a}$ & $10.73 \mathrm{a}$ & $11.47 \mathrm{a}$ & $11.24 \mathrm{a}$ & \\
Container & & &
\end{tabular}

*Averages follow by the same lower case letters in the column do not differ between each other according to the Tukey test at $5 \%$.

A greater emergence velocity is a relevant component to vigor, due to the fact of enabling a fast seedling establishment. Seeds with higher EVI have got better performance and, consequently, greater capacity of resisting to possible stresses (Dan et al., 2010).

\section{Electric conductivity}

For the electric conductivity test, the model that was better suited was the third degree model, for all types of package during storage (Figure 6). In both cultivars, the conductivity increased until two months of storage, with tendency of stabilization until month four and, after that period, there was a new increase, especially between months six and eight. Higher values of electric conductivity are connected to a higher liberation of exudates to the environment through the membrane, indicating greater disruption of those. This corroborates to what was verified for germination (Figure 2), where the more significant drop, in general, occurred after six months of storage.

Regarding the packages, for TMG 1176 RR seeds in the second month of storage, the electric conductivity value was lower in seeds kept in container when compared to those in paper bags, and this relation was inverted in the months four and eight (Table 4). For SYN 9074 RR seeds, the difference between the packages was noticed only in the sixth month of storage, where the seeds kept in big bags showed higher electric conductivity. This reinforces the inference in which even in packages with greater seed mass, it was not efficient in maintaining the temperature during the storage period.

Vieira and Krzyzanowski (1999) observed that in seed lots with high vigor, the electric conductivity values might be no more than $70-80 \mu \mathrm{S} . \mathrm{cm}^{-1} \cdot \mathrm{g}^{-1}$, however with a strong tendency of presenting average vigor. Carvalho et al. (2014b) reinforce the observation that seeds with electric conductivity values between $70-80 \mu \mathrm{S} . \mathrm{cm}^{-1} \cdot \mathrm{g}^{-1}$ present considerable tendency to average vigor. This value was observed in month two and four of storage for seed from the cultivar TMG 1176 RR, and in months two, four and six for SYN 9074 RR seeds (Table 4). Carvalho et al. (2014b) reported, yet, that lower or between $55 \mu \mathrm{S} . \mathrm{cm}^{-1} \cdot \mathrm{g}^{-1}$ and $65 \mu \mathrm{S} . \mathrm{cm}^{-1} \cdot \mathrm{g}^{-1}$ might be associated only to high vigor seeds. Those values were verified only in the 
beginning of the storage (Table 4), when the seeds presented high vigor.
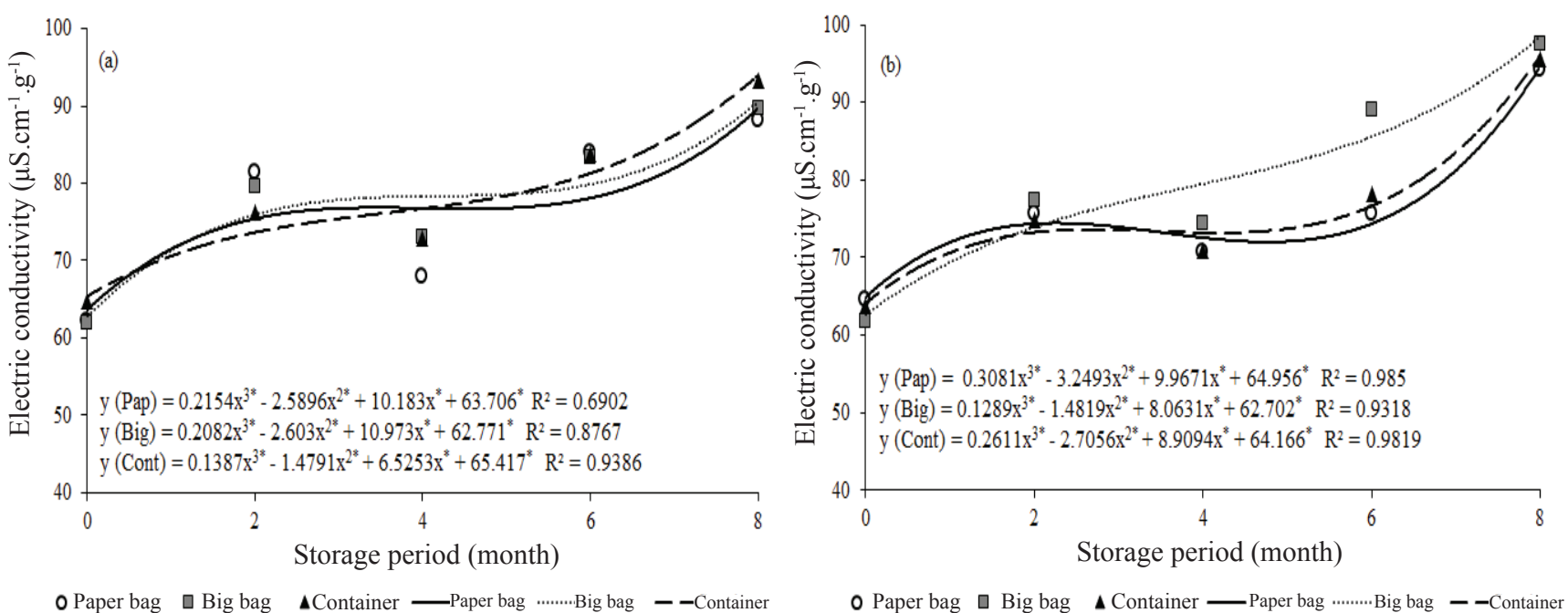

Figure 6. Electric conductivity $\left(\mu \mathrm{S} . \mathrm{cm}^{-1} \cdot \mathrm{g}^{-1}\right)$ of soybean seeds from the cultivars TMG 1176RR (a) and SYN 9074RR (b) in different packages (Paper bags: Pap, Big Bag: Big, Container: Cont), after storage periods (0, 2, 4, 6 and 8 months).

Table 4. Electric conductivity $\left(\mu \mathrm{S} . \mathrm{cm}^{-1} \cdot \mathrm{g}^{-1}\right)$ of soybean seeds from the cultivars TMG $1176 \mathrm{RR}$ and SYN 9074RR in different packages (Paper bags, Big Bag and Container), after storage periods (0, 2, 4, 6 and 8 months).

\begin{tabular}{ccccccccccc}
\hline & \multicolumn{4}{c}{ TMG 1176RR } & \multicolumn{5}{c}{ SYN 9074RR } \\
\cline { 2 - 10 } Package & \multicolumn{4}{c}{ Storage Period (Month) } & \multicolumn{4}{c}{ Storage Period (Month) } \\
\cline { 2 - 11 } & 0 & 2 & 4 & 6 & 8 & 0 & 2 & 4 & 6 & 8 \\
\hline Paper bag & $62.2 \mathrm{a}$ & $81.3 \mathrm{~b}$ & $67.9 \mathrm{a}$ & $84.0 \mathrm{a}$ & $88.2 \mathrm{a}$ & $64.6 \mathrm{a}$ & $75.6 \mathrm{a}$ & $70.6 \mathrm{a}$ & $75.6 \mathrm{a}$ & $94.1 \mathrm{a}$ \\
Big Bag & $61.8 \mathrm{a}$ & $79.5 \mathrm{ab}$ & $72.9 \mathrm{~b}$ & $83.4 \mathrm{a}$ & $89.6 \mathrm{ab}$ & $61.8 \mathrm{a}$ & $77.3 \mathrm{a}$ & $74.3 \mathrm{a}$ & $89.0 \mathrm{~b}$ & $97.5 \mathrm{a}$ \\
Container & $64.7 \mathrm{a}$ & $76.2 \mathrm{a}$ & $72.8 \mathrm{~b}$ & $83.8 \mathrm{a}$ & $93.3 \mathrm{~b}$ & $63.6 \mathrm{a}$ & $74.3 \mathrm{a}$ & $70.9 \mathrm{a}$ & $78.1 \mathrm{a}$ & $95.5 \mathrm{a}$ \\
\hline
\end{tabular}

"Averages follow by the same lower case letters in the column do not differ between each other according to the Tukey test at $5 \%$.

\section{First germination count}

For TMG 1176 RR seeds, the effects of the storage periods were quadratic, regardless of the package and with or without cooling (Figure 7). The highest values were observed near month two of storage, and then the decrease has started in smaller portions until month four. From there on, the decrease was more accentuated, especially after month six. Regarding the package types (Table 5), in the eight month of storage, the smallest averages between the seed which were not cooled were in the big bags and, when cooled, in paper bags.

Between the pre-packaging cooled and not cooled seeds, the only difference was noticed in month eight for TMG 1176 RR seeds stored in big bag and container, where the seeds exposed to cooling showed higher vigor (Table 5). Differences between cooled and not cooled seeds were also determined in the accelerated aging for TMG $1176 \mathrm{RR}$ in month six for seeds in big bags and containers, and month eight in paper bags, and for SYN 9074 RR seeds the averages differ in month six with big bag, always with the cooled seeds presenting higher values (Table 1). The differences were detected only in two tests, isolated and, therefore, inconsistent to infer about a better performance of cooled seeds, in addition to the lack of verification of lower temperatures on the seed mass during storage for those seeds (Figure 1). This allow us to infer the necessity of other possibilities, such as cooling the seed mass to an even lower temperature than the one used, a longer cooling period and other cooling cycles, especially for the region where the study was developed. In Zuchi et al. (2013), the differences for physiological quality of soybean seeds with the pre-packaging cooling were restricted and isolated.

For SYN 9074 RR seeds, the storage effect over the first germination count was of third degree in all packages, and the values were kept practically constant until month four (Figure 8), and then the vigor starts to decrease, with a significant decrease after month six of storage. Between the packages, those differ only in month eight of storage, where 
seeds kept in containers were superior to the others (Table 5).
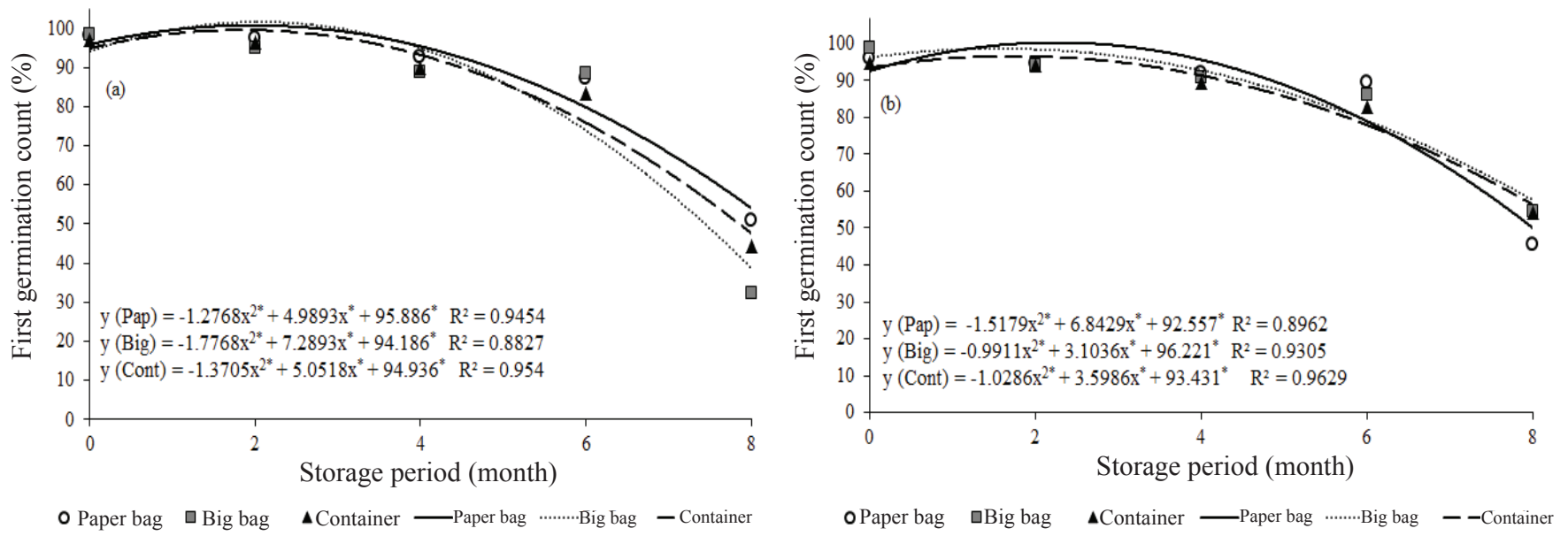

Figure 7. First germination (\%) of soybean seeds from cultivar TMG 1176RR not cooled (a) or cooled (b) before packaging and stored in different packages (Paper bags: Sac, Big Bag: Big, Container: Cont), after storage period (0, 2, 4, 6 and 8 months).

Table 5. First germination count (\%) of soybean seeds from the cultivar TMG 1176RR not cooled (NC) or cooled (C) before packaging and of SYN 9074RR stored in different packages (Paper bags, Big Bag and Container), after storage periods $(0,2,4,6$ and 8 months).

\begin{tabular}{|c|c|c|c|c|c|c|c|c|c|c|}
\hline \multicolumn{11}{|c|}{ TMG 1176RR } \\
\hline \multirow{2}{*}{ Package } & \multicolumn{2}{|c|}{0} & \multicolumn{2}{|c|}{2} & \multicolumn{2}{|c|}{4} & \multicolumn{2}{|c|}{6} & \multicolumn{2}{|c|}{8} \\
\hline & $\mathrm{NC}$ & $\mathrm{C}$ & $\mathrm{NC}$ & $\mathrm{C}$ & $\mathrm{NC}$ & $\mathrm{C}$ & $\mathrm{NC}$ & $\mathrm{C}$ & $\mathrm{NC}$ & $\mathrm{C}$ \\
\hline Paper bag & $98 \mathrm{a}$ & $96 \mathrm{a}$ & $98 \mathrm{a}$ & $95 \mathrm{a}$ & $93 \mathrm{a}$ & $92 \mathrm{a}$ & $87 \mathrm{a}$ & $90 \mathrm{a}$ & $51 \mathrm{a}$ & $46 \mathrm{~b}$ \\
\hline Big Bag & 99 a & 99 a & $95 \mathrm{a}$ & $94 \mathrm{a}$ & 89 a & $91 \mathrm{a}$ & $88 \mathrm{a}$ & $86 \mathrm{a}$ & $33 \mathrm{Bb}$ & $54 \mathrm{Aa}$ \\
\hline Container & $97 \mathrm{a}$ & $95 \mathrm{a}$ & $98 \mathrm{a}$ & $94 \mathrm{a}$ & $90 \mathrm{a}$ & $90 \mathrm{a}$ & $83 \mathrm{a}$ & $83 \mathrm{a}$ & $44 \mathrm{Ba}$ & $54 \mathrm{Aa}$ \\
\hline \multicolumn{11}{|c|}{ SYN 9074RR } \\
\hline Package & \multicolumn{2}{|c|}{0} & \multicolumn{2}{|c|}{2} & \multicolumn{2}{|c|}{4} & \multicolumn{2}{|c|}{6} & \multicolumn{2}{|c|}{8} \\
\hline Paper bag & \multicolumn{2}{|c|}{$95 \mathrm{a}$} & \multicolumn{2}{|c|}{$94 \mathrm{a}$} & \multicolumn{2}{|c|}{$91 \mathrm{a}$} & \multicolumn{2}{|c|}{$82 \mathrm{a}$} & \multicolumn{2}{|c|}{$42 \mathrm{~b}$} \\
\hline Big Bag & \multicolumn{2}{|c|}{$95 \mathrm{a}$} & \multicolumn{2}{|c|}{93 a } & \multicolumn{2}{|c|}{$90 \mathrm{a}$} & \multicolumn{2}{|c|}{$82 \mathrm{a}$} & \multicolumn{2}{|c|}{$43 \mathrm{~b}$} \\
\hline Container & \multicolumn{2}{|c|}{$96 \mathrm{a}$} & \multicolumn{2}{|c|}{$93 \mathrm{a}$} & \multicolumn{2}{|c|}{$91 \mathrm{a}$} & \multicolumn{2}{|c|}{$83 \mathrm{a}$} & \multicolumn{2}{|c|}{$49 \mathrm{a}$} \\
\hline
\end{tabular}

"Averages followed from the same lower case letter in the column do not differ between each other according to the Tukey test at $5 \%$. Capital letters in the line, in each storage period, present significant differences according to the variance analysis, $\mathrm{p}<0.05$ by the $\mathrm{F}$ test.

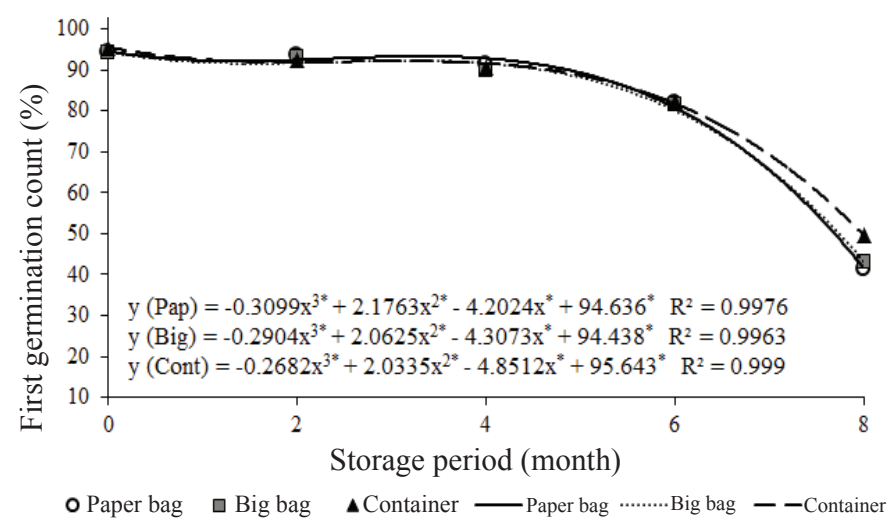

Figure 8. First germination (\%) of soybean seeds from cultivar SYN 9074RR not cooled (a) or cooled (b) before packaging and stored in different packages (Paper bags: Pap , Big Bag: Big, Container: Cont), after storage period (0, 2, 4, 6 and 8 months). 


\section{Conclusions}

The use of packages with greater seed quantities (big bag and container) do not favors the mass cooled temperature maintenance in the pre-packaging process.

The types of packages tested do not provide differences in the viability of soybean seeds during storage, until the eighth month, regardless of the pre-packaging cooling.

Seeds from cultivars presented different tolerances in storage, where seeds from the cultivar TMG 1176 RR had lower storage potential than SYN 9074 RR seeds.

\section{Acknowledgments}

To the 'Conselho Nacional de Desenvolvimento Científico e Tecnológico (CNPq)', for scholarship consession. To CNPq, to the 'Coordenação de Aperfeiçoamento de Pessoal de Nível Superior (CAPES)', to the 'Fundação de Amparo à Pesquisa de Minas Gerais (FAPEMIG)' and to the company AMAGGI for its support.

\section{References}

AGUIAR, R.W.S.; BRITO, D.R.; OOTANI, M.A.; FIDELIS, R.R.; PELUZIO, J.N. Efeito do dióxido do carbono, temperatura e armazenamento sobre sementes de soja e micoflora associada. Revista Ciência Agronômica, v.43, n.3, p.554-560, 2012. http://www.ccarevista.ufc.br/seer/index.php/ ccarevista/article/view/1596/718

ALMEIDA, F.A.C.; JERÔNIMO, E.S.; ALVES, N.M.C.; GOMES, J.P.; SILVA, A.S. Estudo de técnicas para o armazenamento de cinco oleaginosas em condições ambientais e criogênicas. Revista Brasileira de Produtos Agroindustriais, v.12, n.2, p.189-202, 2010. http://www.deag.ufcg.edu.br/ rbpa/rev122/Art1220.pdf

ÁVILA, M.R.; ALBRECHT, L.P. Isoflavonas e a qualidade das sementes de soja. Informativo Abrates, v.20, n.1,2, p.15-29, 2010. http://www.abrates.org. br/images/stories/informativos/v20n12/artigo02.pdf

BESSA, J. F.V.; DONADON, J.R.; RESENDE, O.; ALVES, R.M.V.; SALES, J.D.F.; COSTA, L.M. Armazenamento do crambe em diferentes embalagens e ambientes: Parte I - Qualidade fisiológica. Revista Brasileira de Engenharia Agricola e Ambiental, v.19, n.3, p.224-230, 2015. http://www.scielo.br/pdf/ rbeaa/v19n3/1415-4366-rbeaa-19-03-0224.pdf

BRASIL. Ministério da Agricultura, Pecuária e Abastecimento. Regras para análise de sementes. Ministério da Agricultura, Pecuária e Abastecimento. Secretaria de Defesa Agropecuária. Brasília: MAPA/ACS, 2009. 395p. http:// www.agricultura.gov.br/arq_editor/file/2946_regras_analise_sementes.pdf

CARDOSO, R.B.; BINOTTI, F.F.S.; CARDOSO, E.D. Potencial fisiológico de sementes de crambe em função de embalagens e armazenamento. Pesquisa Agropecuária Tropical, v. 42, n.3, p.272-278, 2012. www.revistas.ufg.br/index. php?journal= $=$ at\&page $=$ article\&op=view\&path $\% 5 \mathrm{~B} \% 5 \mathrm{D}=17249 \&$ path $\% 5 \mathrm{~B} \%$ $5 \mathrm{D}=11530$
CARVALHO, E.R.; MAVAIEIE, D.P.R.; OLIVEIRA, J.A.; CARVALHO, M.V.; VIEIRA, A.R.; Alterações isoenzimáticas em sementes de cultivares de soja em diferentes condições de armazenamento. Pesquisa Agropecuária Brasileira, v.49, n.12, p.967-976, 2014a. http://www.scielo.br/pdf/pab/ v49n12/0100-204X-pab-49-12-00967.pdf

CARVALHO, E.R.; OLIVEIRA, J.A.; CALDEIRA, C.M. Physiological quality of seeds in conventional and glyphosate-resistant soybean produced by foliar. Bragantia, v. 73, n. 3, p.219-228, 2014b. http://www.scielo.br/pdf/ brag/v73n3/en_aop_brag_0096_pt.pdf

CARVALHO, N.M.; NAKAGAWA, J. Sementes: ciência, tecnologia e produção. Jaboticabal: FUNEP, 2012. 590p.

CUNHA, J.P.A.R.; OLIVEIRA, P.; SANTOS, C.M.; MION, R.L. Qualidade das sementes de soja após a colheita com dois tipos de colhedora e dois períodos de armazenamento. Ciência Rural, v.39, p.1420-1425, 2009. http:// www.scielo.br/pdf/cr/2009nahead/a169cr286.pdf

DAN, L.G.M.; DAN, H.A.; BARROSO, A.L.L.; BRACCINI, A.L. Qualidade fisiológica de sementes de soja tratadas com inseticidas sob efeito do armazenamento. Revista Brasileira de Sementes, v.32, n.2, p.131-139, 2010. http://www.scielo.br/pdf/rbs/v32n2/v32n2a16.pdf

DEMITO, A.; AFONSO, A.D.L. Qualidade das sementes de soja resfriadas artificialmente. Engenharia na Agricultura, v.17, n.1, p.7-14, 2009. http:// www.agrolink.com.br/downloads/128572.pdf

ESTEVÃO, C.P. Qualidades fisiológica e sanitária de sementes de soja tratadas e armazenadas em diferentes ambientes. Scientia Agraria, v.3, p.113113, 2002. http://ojs.c3sl.ufpr.br/ojs2/index.php/agraria/article/view/1040

FERREIRA, D.F. Sisvar: a computer statistical analysis system. Ciência e Agrotecnologia, v.35, n.6, p.1039-1042, 2011. http://www.scielo.br/pdf/ cagro/v35n6/a01v35n6.pdf

JUVINO, A.N.K.; RESENDE, O.; COSTA, L.M.; SALES, J.F. Vigor da cultivar BMX Potência RR de soja durante o beneficiamento e períodos de armazenamento. Revista Brasileira de Engenharia Agrícola e Ambiental, v.18, n.8, p.844-850, 2014. http://www.agriambi.com.br/revista/v18n08/ v18n08a10.pdf

LIMA, D.C.; DUTRA, A.S.; CAMILO, J.M. Physiological quality of sesame seeds during storage. Revista Ciência Agronômica, v.45, n.1, p.138-145, 2014. http://www.scielo.br/pdf/rca/v45n1/17.pdf

MAGUIRE, J.D. Speed of germination aid in selection and evaluation for seedling and vigor. Crop Science, v.2, n.2, p.176-177, 1962. https:// dl.sciencesocieties.org/publications/cs/abstracts/2/2/CS0020020176

MARCOS - FILHO, J. Teste de envelhecimento acelerado. In: KRZYZANOWSKI, F.C.; VIEIRA, R.D.; FRANÇA-NETO, J.B. (Ed.). Vigor de sementes: conceitos e testes. Londrina: ABRATES, 1999. p.3.24-3.32.

SANTOS, C.M.R.; MENEZES, N.L.; VILELA, F.A. Alterações fisiológicas e bioquímicas em sementes de feijão envelhecidas artificialmente. Revista Brasileira de Sementes, v. 26, n. 1, p. 110-119, 2004. http://www.scielo.br/ $\mathrm{pdf} / \mathrm{rbs} / \mathrm{v} 26 \mathrm{n} 1 / \mathrm{a} 17 \mathrm{v} 26 \mathrm{n} 1 . \mathrm{pdf}$

SMANIOTTO, T.A.S.; RESENDE, O.; MARÇAL, K.A.F.; OLIVEIRA, D.E.C.; SIMON, G.A. Qualidade fisiológica das sementes de soja armazenadas em diferentes condições. Revista Brasileira de Engenharia Agrícola Ambiental, v.18, n.4, p.446-453, 2014. http://www.agriambi.com. br/revista/v18n04/v18n04a13.pdf 
SMIDERLE, O.J.; GIANLUPPI, V. Ambiente controlado para armazenamento e qualidade de sementes de soja em Roraima. Boa Vista: Embrapa Roraima, 2006. 5p. (Comunicado Técnico, 14).

TOLEDO, M.Z.; FONSECA, N.R.; CESAR, M.L.; SORATTO, R.P.; CAVARIANI, C.; CRUSCIOL, C.A.C. Qualidade fisiológica e armazenamento de sementes de feijão em função da aplicação tardia de nitrogênio em cobertura. Pesquisa Agropecuária Tropical, v.39, n.2, p.124133, 2009. http://www.redalyc.org/pdf/2530/253020166008.pdf

VIEIRA, B.G.T. L.; VIEIRA, R.D.; KRZYZANOWSKI, F.C.; FRANÇANETO, J.B. Alternative procedure for the cold test for soybean seeds. Scientia Agricola, v.67, n.5, p.540-545, 2010. http://www.revistas.usp.br/sa/ article/view/22599/24623
VIEIRA, R. D.; KRZYZANOWSKI, F. C. Teste de condutividade elétrica. In: KRZYANOWSKI, F. C.; VIEIRA, R. D.; FRANÇA-NETO, J. B. (Ed.). Vigor de sementes: conceitos e testes. Londrina: ABRATES, 1999. cap.4, p.1-26.

VILLELA, F.A.; MENEZES, N.L. O potencial de armazenamento de cada semente. Seed News, v.8, n.4, p.22-25, 2009. http://www.seednews.inf.br/ $\mathrm{html} /$ site/content/home/index.php

ZUCHI, J.; FRANÇA-NETO, J.B.; SEDIYAMA, C.S.; LACERDA FILHO, A.F.; REIS, M.S. Physiological quality of dynamically cooled and stored soybean seeds. Journal of Seed Science, v.35, n. 3, p. 353-360, 2013. http:// www.scielo.br/pdf/jss/v35n3/12.pdf 